\title{
POLÍTICAS MONÁRQUICAS FRENTE A LA PROPIEDAD COMUNAL EN LOS CONCE- JOS DE REALENGO CASTELLANOS BAJOMEDIEVALES
}

\section{CORINA LUCHÍA}

Universidad de Buenos Aires - CONICET

RESUMEN: El presente estudio se propone comprender las ambigüedades de la política de la monarquía respecto de la propiedad comunal en el área concejil castellana durante la baja Edad Media. La relación entre el poder central y los grupos dominantes locales configura una red de relaciones que oscilan entre la negociación y la competencia. La propiedad colectiva, defendida a veces, atacada otras, forma parte de esa compleja trama de intereses que articulan la dominación del reino.

La necesidad de la Corona de garantizarse apoyos a nivel local, en muchas ocasiones entra en contradicción con los avances señoriales sobre las tierras comunes que ponen en riesgo la capacidad imperativa de los soberanos así como su base de reproducción social, en tanto la privatización de los espacios y la imposición de los poderes coactivos sobre las comunidades, implica la pérdida de rentas reales. Las oscilaciones del comportamiento regio en relación a la preservación de la propiedad colectiva responden al delicado equilibrio entre la monarquía y las fuerzas que sostienen la dominación feudal en las villas y aldeas.

Palabras Clave: Monarquía. Propiedad comunal. Poderes locales. Baja Edad Media. Castilla.

\section{ROYAL POLICIES REGARDING COMMON LANDS IN LATE MEDIEVAL CASTILIAN COUNCILS OF REALENGO}

ABSTRACT: The aim of this study is to understand the oscillations of royal policy regarding common lands in the area of Castilian councils during the later Middle Ages. The relation between the central power and the dominant local groups is analysed, which reveals a set of policies ranging from negotiation to competence. Collective property, which is sometimes defended and sometimes attacked, is part of the complex framework of interests through which royal domination is articulated.

The Crown need of support at the local level often contradicts the seigneurial attemps to invade common lands, which put at risk the political authority of the king as well as his base of social reproduction, inasmuch as both the privatization of commons and the imposition of coercive powers over communities imply a decrease in the level of royal revenues. The oscillations that royal behaviour shows with 
regard to common property protection responds to the delicate balance between the monarchy and the forces that supports feudal domination in the cities and villages.

KEY WORDS: Monarchy. Common property. Local powers. Later Middle Ages. Castile.

\section{Presentación}

Las comunidades campesinas castellanas basan su fortaleza en una sólida estructuración material que se remonta a los tiempos de la instalación en el área. Entre los elementos que componen el temprano modo material de producción, entendido éste como el conjunto de prácticas concretas por medio de las cuales los colectivos campesinos explotan productivamente el espacio agrario, se destaca la complementariedad entre la tenencia particular y una trama de relaciones de apropiación colectiva de los suelos abiertos que constituye la propiedad comunal de villas y aldeas ${ }^{1}$. Los términos comunes son espacios centrales para la reproducción económica de los distintos sectores sociales y resultan continuo objeto de disputas. Los tributarios pobres, las distintas fracciones de la nobleza, incluyendo a la propia monarquía, así como la caballería villana y el sector enriquecido de las aldeas pugnan por el aprovechamiento de estos suelos.

En el presente trabajo se abordarán las formas de intervención del poder monárquico en relación a la propiedad comunitaria de los concejos castellanos de realengo en los siglos finales de la Edad Media. Para ello circunscribiremos nuestra indagación a todos los bienes de uso libre y gratuito cuya propiedad eminente pertenece al soberano, a los que acceden los vecinos y moradores de las aldeas y las villas en calidad de poseedores de su dominio útil.

Si bien existen estudios sobre este tipo de propiedad, su centralidad social y productiva no se tradujo en una valoración suficiente por parte de la historiografía ${ }^{2}$, de ahí que representen un renovado objeto de interés para observar su

${ }^{1}$ Diferenciamos el concepto de modo material de producción del de modo de producción en sentido estricto, tal como lo definen Marx y Engels: «Es ya, más bien, un determinado modo de la actividad de estos individuos, un determinado modo de manifestar su vida, un determinado modo de vida de los mismos», MARX, Kart y Engels, Friederich, La Ideología Alemana, Bs. As., Ed. Pueblos Unidos, 1985, pág. 19.

${ }^{2}$ La escasez de trabajos sobre la cuestión es señalada por MONSALVo ANTÓN, J.M., «Paisaje agrario, régimen de aprovechamientos y cambio de propiedad en una aldea de la tierra de Ávila durante el siglo XV. La creación del término redondo de Zapardiel de Serrezuela», Cuadernos Abulenses, 17 (1992), págs. 11-110. En igual sentido se pronuncia García Sanz: «La temática de los bienes y aprovechamientos comunales constituye, pues, en la Castilla del siglo XVI, una problemática de la suficiente trascendencia como para plantear la necesidad de superar su estudio a nivel de referencia genérica o de comentario trivial», GARCía SANZ, Ángel, «Bienes y derechos comunales y el proceso de su privatización en Castilla durante los siglos XVI y XVII: El caso de tierras de Segovia», Hispania, 144 (1980), págs. 95-127/ 109. Por su parte, Carmona Ruiz indica que pese al reducido número de estudios sobre los aprovechamientos comunales en España, la 
compleja relación con las estrategias de la Corona ${ }^{3}$. No obstante, en las contribuciones sobre distintos aspectos del comportamiento monárquico, como la política monetaria, fiscal, administrativa o la estructuración del régimen político existen elementos para reconstruir las orientaciones de la política real frente a los bienes comunes ${ }^{4}$.

La política regia respecto de la propiedad colectiva ha sido estudiada desde las acciones de los soberanos que inciden en su integridad y preservación o en su merma y privatización. Los términos colectivos se presentan como un espacio sobre el que se lanzan recurrentes ofensivas que culminarán en el largo desarrollo histórico con su desaparición ${ }^{5}$. Sin embargo, esta mirada impide reconocer la fortaleza y perdurabilidad de la propiedad comunitaria dentro del régimen feudal, su centralidad en las diferentes modalidades de transición al capitalismo, así como el papel que cumple en las relaciones de poder del reino, aspectos que posibilitan comprender la abigarrada política del poder monárquico.

Algunos autores atribuyen la conducta de la monarquía a razones de estricta índole fiscal, asociándola a las urgencias financieras que motivan la presión sobre los comunes de los concejos ${ }^{6}$. En otra clave de análisis se encuentran las

preocupación de los regeneracionistas de finales del siglo XIX y comienzos del XX ha creado una tradición importante sobre el tema, aunque no superada hasta la actualidad, CARMONA RUIZ, María Antonia, La ganadería en el Reino de Segovia durante la Baja Edad Media, Sevilla, 1998.

3 Un breve estado de la cuestión sobre los bienes comunales de Castilla la Vieja y León durante la Edad Moderna en RUBio PÉREZ, Laureano, «Campo, campesinos y cuestión rural en Castilla la Vieja y en el reino de León durante la Edad Moderna. Estado de la cuestión, claves y valoraciones de conjunto", Studia Historica (Moderna), 29 (2007), págs. 83-177.

4 Destacamos los trabajos de LADERO QuesAdA, Miguel Ángel, La Hacienda real de Castilla en el siglo XV, Sevilla, La Laguna, 1973; AstariTA, Carlos, "Estudio sobre el concejo medieval de la Extremadura castellano-leonesa. Una propuesta para resolver su problemática», Hispania, vol. 42, 151 (1982), págs. 355-413; Astarita, Carlos, «Estructura social del concejo primitivo de la Extremadura castellano-leonesa, Problemas y controversias», Anales de Historia Antigua y Medieval, 26 (1993), págs. 47-118; Astarita, Carlos, «Dinámica del sistema feudal, marginalidad y transición al capitalismo», en: CARrillo, S. et. al, Disidentes, heterodoxos y marginados en la historia, Salamanca, 1997, págs. 21-49; Astarita, Carlos, Del feudalismo al capitalismo, Valencia, Univ. de Granada, 2005; PASTOR, Reyna, Conflictos sociales y estancamiento económico en la España Medieval, Barcelona, 1973; YUN CASALILLA, Bartolomé, Sobre la transición al capitalismo en Castilla (1500-1830). Economía y Sociedad en Tierra de Campos, Junta de Castilla y León, CEC, 1987; MONSALvo ANTón, J.M., «Poder político y aparatos de estado en la Castilla bajomedieval. Consideraciones sobre su problemática», Studia Histórica (Medieval), 2 (1986), págs. 100-167; AstaRita, Carlos, El sistema político concejil. El ejemplo del señorío medieval de Alba de Tormes y su concejo de villa y tierra, Salamanca, 1988; Diago Hernando, Máximo, Soria en la Baja Edad Media. Espacio rural y economía agraria, Madrid, Ed. Complutense, 1993.

5 Dos de los trabajos más representativos de esta orientación general son Gómez MENDOZA, Josefina, «La venta de baldíos y comunales en el siglo XVI. Estudio de su proceso en Guadalajara», Estudios geográficos, 28 (1967), págs. $499-559$ y VASSBERG, David, La venta de tierras baldías. El comunitarismo agrario y la Corona de Castilla durante el siglo XVI, Madrid, Servicio de Publicaciones Agrarias, 1983.

${ }^{6}$ UlLOA, Modesto, La Hacienda real de Castilla en el Reinado de Felipe II, Madrid, FuE, 1977, pág. 660. Este autor considera que el objetivo de la Corona al apoyar la creciente privatización «no 
tesis que reconocen en las alteraciones demográficas el principal determinante de los cambios de la política del poder central frente a los términos públicos. El eje de estos planteos es la evolución desde la temprana concesión de términos a las comunidades para estimular el asentamiento poblacional, hasta la reversión de esta tendencia en contextos de alza demográfica, cuando se opera la parcelación y privatización del patrimonio colectivo ${ }^{7}$. Si bien estos aportes son de indudable interés, el conocimiento de la política de la Corona frente a la propiedad colectiva, pública y abierta resulta enriquecido si se vinculan los elementos fiscales y demográficos ${ }^{8}$ a los condicionamientos que impone el entramado de las relaciones de poder a nivel local. La ausencia de una política monárquica uniforme, que se expresa en divergencias sustanciales entre las medidas tomadas para diferentes lugares de la misma área, revelan un entramado táctico y estratégico de disposiciones cambiantes que se orientan a mantener un balance de fuerzas favorable al ordenamiento económico y político de cada región, en un complejo equilibrio que sostiene la construcción política general.

La monarquía, desde el siglo XIII, interviene como agente regulador de la vida concejil, de manera ambivalente y, en ocasiones, contradictoria9. Las oscilaciones de las disposiciones regias no se comprenden desde el plano abstracto de los enunciados programáticos del poder central, sino a partir de las condiciones particulares en las que se estructura la dominación. La política real responde tanto a objetivos inmediatos de satisfacción de rentas en períodos de dificultades financieras, como a otros de alcance estructural vinculados a garantizar la reproducción de sus bases sociales.

Si el comportamiento de los soberanos no sólo es producto de las coyunturas fiscales, financieras, demográficas o ecológicas, consideramos de indudable

era cambiar el régimen de posesión de la tierra, sino recaudar». Si bien, desde una perspectiva más amplia, también se enfatiza el factor de la crisis financiera en la obra de Yun Casalilla, quien explica la política de ventas de tierras baldías como producto de las necesidades de la monarquía ante la crisis del siglo XVII, Yun Casalilla, B., Sobre la transición al capitalismo en Castilla..., pág. 285. Para García Sanz la política real de concesión de fueros, cartas de población y señoríos jurisdiccionales, al igual que el ordenamiento de la trashumancia, actúan como una fuerza disolvente del patrimonio comunal, a partir de las necesidades financieras del reino, GARCía SANZ, A., «Bienes y derechos comunales y el proceso de su privatización en Castilla...».

7 ForTea PÉREZ, José Ignacio, «La propiedad de las corporaciones urbanas», en: De Dios, Salustiano, Infante, Javier, Robledo, Ricardo, Torijano, Eugenia, (coords.), Historia de la propiedad en España. Siglos XV-XX. Encuentro interdisciplinar, Salamanca, 1998, págs. 61-112. Carmona Ruiz asocia la presión demográfica del siglo XV con la merma de las tierras baldías y su reconversión de pasturas a cultivos, CARMONA RUIZ, M.A., La Ganadería...

${ }^{8}$ El trabajo de Diago Hernando reúne ambos factores, articulando demografía y fiscalidad en una trama de intereses políticos y económicos más vastos, Diago Hernando, M., Soria en la Baja Edad Media...

9 Diago Hernando advierte esta particularidad de la conducta monárquica atendiendo a una multiplicidad de factores que inciden en la ambivalencia de las distintas instituciones regias frente al problema, Diago Hernando, M., Soria en la Baja Edad Media... 
valor incorporar la dimensión del poder. En este sentido se explorará el papel que juega la delicada relación de la Corona con los poderes locales, en términos de alianzas y concesiones, competencia y enfrentamientos. El estudio empírico se concentra en la documentación local proveniente del área concejil de realengo, con particular referencia a las fuentes abulenses, cuyas numerosas ordenanzas concejiles junto con la documentación judicial, como los pleitos recopilados en el Asocio de Ávila, dan cuenta de las prácticas efectivas que se realizan sobre el espacio y exhiben la profunda conflictividad que atraviesa la propiedad comunal. El diálogo entre lo general y lo particular es posible con la incorporación de documentos reales, como las peticiones de Cortes, que expresan el modo en que se procesan las contradicciones de cada concejo.

Por último, consideramos necesario aclarar que la exposición de las distintas modalidades de intervención monárquica no seguirá una lineal ordenación cronológica; en cambio, se tratará de identificar los diferentes tipos de políticas en función de los condicionamientos que están presentes en distintas coyunturas.

\section{DIFERENTES MODALIDADES DE INTERVENCIÓN MONÁRQUICA}

\section{Concesiones y definición doctrinal}

Las primeras referencias del poder central sobre la propiedad comunal aparecen en las donaciones que otorgan términos a las comunidades para su libre usufructo. En la etapa de la repoblación, el soberano, con la usual fórmula «dono et concedo montes, pinares, pasqua, prata, extremos populator et eremos, totos ex integro» ${ }^{10}$, más que conceder, confirma como derecho lo que existía como práctica desde que memoria de omne non es en contrario. Esta persistencia de las tradiciones agrarias da cuenta de la importancia del modo material de producción en la estructuración del feudalismo ${ }^{11}$. La dotación de espacios comunales reflejada en los distintos fueros indica la gravitación que estos espacios tuvieron desde los tiempos más tempranos de la organización feudal en el área.

${ }^{10}$ Concesión efectuada por Alfonso VIII al Concejo de Madrid validando la posesión antigua de sus pastos y montes, el 31 de enero de 1176, GonZÁLEZ, Julio, El reino de Castilla en la época de Alfonso VIII, Madrid, CSIC, 1960, T. II, Doc. 242.

${ }_{11}$ Acerca del rol de las comunidades campesinas en la estructuración del feudalismo y en el condicionamiento de sus formas políticas: «La reproducción extensiva o espacial del modo de producción feudal, en una parte de su frontera, se realizó mediante la actividad de una comunidad campesina libre. Entre la comunidad y la expansión del feudalismo existió una interacción dialéctica, ya que aquélla preparó las condiciones para nuevas relaciones sociales otorgando características específicas al área, y a su vez, el feudalismo en expansión determinaba que el desarrollo de la comunidad se diera en un marco predefinido", AstariTA, C., Del feudalismo al capitalismo..., 2005, pág. 94. 
Señala el Fuero de Plasencia ${ }^{12}$, otorgado inicialmente por Alfonso VIII y confirmado sucesivamente por Sancho IV y Fernando IV:

«En lo primero mando et otorgo a los pobladores de Plazencia, Plazencia con todo su termino, con montes et con fuentes et con pasceduras et con rios, con salinas et con uenas de plata et con uenas de fierro et de metallo»13.

Esta concesión importa el reconocimiento de las formas socioeconómicas precedentes, que comprenden el conjunto de recursos materiales que históricamente eran fuente de susbsistencia de los pobladores. El poder central no sólo no puede obviar la importancia de estos bienes sino que los reconoce como elementos constitutivos de la vida comunitaria, al punto que la entrega de los mismos va acompañada del derecho consuetudinario a defenderlos frente a los extraños:

«Et si por auentura omne de otra uila en uestro termino falardes uenando con aues o con canes, o con redes o con balesta, o pescando, o madera taiando o lenna, faziendo sal o fierro, prendello sin calonna et despechalo como a moro» ${ }^{14}$.

El soberano, al mismo tiempo que configura el entramado institucional del reino subordinando a los concejos al vértice superior, les reconoce un poder que generará numerosos conflictos a lo largo de la Baja Edad Media's, en tanto pone en sus manos la capacidad de guarda del patrimonio público, delimitando las jurisdicciones entre las diferentes entidades aldeanas y villanas.

En los fueros y cartas pueblas se expresa un tipo de intervención monárquica que es tanto de carácter local, al reconocer la particularidad de cada ciudad y su entorno, como general, puesto que instrumenta una verdadera política de estado respecto de la consolidación de las bases productivas del feudalismo. El modo material de producción es un condicionante fundamental de toda la construcción política y legislativa, de allí que la definición doctrinal del patrimonio público sea posterior a su reafirmación en el nivel de las prácticas concretas, de las cuales dan cuenta los primeros fueros otorgados ${ }^{16}$.

\footnotetext{
12 Normativas semejantes se encuentran en el Fuero de Cuenca. Edición crítica, con introducción, notas y apéndice, Libro I, Tit. I, Madrid, Tipografía de Archivos, 1935. Véase también, RIU, Manuel, «Agricultura y ganadería en el Fuero de Cuenca», Anuario de Estudios Medievales, 12 (1992), págs. 67-181.

13 Ramírez VaQuero, Eloisa, El Fuero de Plasencia, Mérida, Junta de Extremadura, 1987, pág. 67.

${ }^{14}$ Ramírez VAquero, Eloisa, El Fuero de Plasencia...

${ }^{15}$ La figura del guarda o montaraz es de vital importancia en la custodia de estos bienes: $\mathrm{Si}$ ganado de otra uila en termino de Plazencia o en sus terminos o estremos a pacer entrare, el conceio quintelo sin calonna et después saquelo de sus terminos et este quinto (to) menlo de oueias et de vacas et de puercos et de yeguas et de todo ganado, RAmírez VAQUero, Eloisa, El Fuero de Plasencia...

16 Véase, por ejemplo, Fueros Leoneses de Zamora, Salamanca, Ledesma y Alba de Tormes. Edición y Estudio de Américo CASTRO y Federico DE ONís, Madrid, Junta para la ampliación de estudios e investigaciones científicas, Centro de estudios históricos, 1916.
} 
La definición jurídica de estos bienes aparecerá en el contexto de la ofensiva centralista de Alfonso $\mathrm{X}^{17}$, con la promulgación de las Siete Partidas:

«son establecidos e otorgados para procomunal de cada çibdad o villa o castillo o lugar. Ça todo omme que fuere y morador puede usar de todas estas cosas sobredichas: e son comunales a todos, tambien a los pobres como a los ricos. Mas los que fuesen moradores en otro lugar non pueden usar de ellas contra voluntad o defendimiento de los que morasen $\mathrm{y}^{» 18}$.

La obra alfonsina tiende a definir jurídicamente un tipo de propiedad cuya imprecisión la convierte en objeto de permanentes abusos ${ }^{19}$. El carácter disperso de los comunales los vuelve dificultosamente delimitables ${ }^{20}$, aunque las sucesivas disposiciones pretenden fijarlos, al menos desde lo legal. Son comunales todos aquellos bienes vinculados que permanecen fuera de los circuitos de comercialización ${ }^{21}$ y en un sentido más amplio, los términos

«cuya explotación revierte en beneficio de una comunidad, bien de forma individual, como complemento a la economía de cada uno de los vecinos, bien de forma colectiva, como forma de paliar las necesidades económicas de un concejo»22.

La monarquía confirma los derechos de las comunidades sobre tierras que le pertenecen en última instancia, en tanto el estado, verdadero propietario de los términos públicos de los concejos de realengo, está encarnado en ella ${ }^{23}$. La concesión-reconocimiento de los términos colectivos configura una política de entrega de tierras y de confirmación de su libre disposición por parte de las entidades campesinas. En este sentido, la Corona reafirma las bases materiales de la

17 Esta ofensiva se aprecia en el lugar preeminente se otorga al Soberano: «Naturalmiente el rrey es cabeça de ssu rreyno e es ayuntamiento de ssu pueblo e vida e asentamiento dellos para fazer aver a cada uno el lugar quel conviene e guardarlos en uno que non sse departan (...)», MARTíNEZ DiEz, Gonzalo, (ed.), Leyes de Alfonso X. I. Especulo, Ávila, 1985, págs. 115-116.

${ }_{18}$ Códigos españoles acordados y anotados, I- IV, Partidas, III, XXVIII, 9, Madrid, 1872.

19 Este aspecto de la propiedad comunal es reconocido por YUN CASALILLA, B., Sobre la transición al capitalismo en Castilla...; MANGAS NAVAS, José, El régimen comunal agrario de los concejos de Castilla, Madrid, Servicio de Publicaciones Agrarias, 1981; MOnSAlvo ANTón, J.M., «Usurpaciones de comunales: conflicto social y disputa legal en Ávila y su Tierra durante la Baja Edad Media», Historia Agraria, 24 (2001).

${ }^{20}$ Un texto tardío confirma esta cualidad de la propiedad comunal: «La cantidad de los bienes comunales o concejiles y de los baldíos es muy difícil de conocer, porque ni su uso ni su propiedad convienen con su nombre», DE BORJAS Y TARRIUS, Bernardo, Estadística territorial de la provincia de Avila, formada de orden superior en la sección primera del departamento de Fomento General del Reyno y de la Balanza de Comercio, Madrid, 1804, pág. XVII.

21 Marcos Martín, Alberto, «Estructuras de la propiedad en la época moderna: Evolución y variantes peninsulares», en: DE Dios, S., Infante, J., Robledo, R., Torijano, E., (coords.), Historia de la propiedad en España..., págs. 113-162.

22 Carmona RuIZ, M.A., La ganadería..., págs. 99-100.

23 Mangas Navas, J.M., El régimen comunal agrario... 
masa tributaria, al tiempo que articula un juego subordinante de reciprocidades con los ingentes grupos locales que constituirán los sectores privilegiados de los concejos ${ }^{24}$.

Factores materiales arraigados en las prácticas agrarias campesinas por un lado, y necesidades políticas del reino, por otro, determinan el comportamiento de los soberanos en esta etapa. Sin embargo, como veremos más adelante, la política inicial de otorgamiento de suelos comunes por parte de la Corona no se limita a esta fase fundacional, sino que se recrea en contextos de plena consolidación del régimen sociopolítico. Esto se aprecia en la concesión de privilegios reales que satisfacen la demanda de términos por parte de numerosos concejos; de allí la advertencia precedente acerca del ordenamiento conceptual y no cronológico de este estudio.

\section{Entre la mediación protectora y la ofensiva sobre los comunales}

Si bien los conflictos por los comunales atraviesan toda la Edad Media, se acrecientan a partir de la segunda mitad del siglo XIV. Las denuncias de los procuradores aldeanos y villanos por las tomas y usurpaciones de términos se multiplican hasta llegar a las máximas instancias del reino ${ }^{25}$. Las reuniones de Cortes y los reiterados pleitos judiciales proveen de una rica información que da cuenta de la amplitud del fenómeno y sirven en este apartado como principal referencia erudita. La densa conflictividad que se desata en este período involucra las disputas entre concejos y apropiadores privados - en su gran mayoría señores, grandes propietarios villanos y sectores aldeanos enriquecidos- así como entre los distintos concejos e incluso entre estos y la monarquía ${ }^{26}$.

La lucha jurisdiccional entre comunidades por el deslinde de sus términos públicos se agrava por la rivalidad entre concejos de villa y de aldea. Dicha rivalidad expresa las contradicciones sociales de todo el sistema concejil, agudizadas por la política regia de concesión de villazgos que marca, hacia finales del siglo XIV, un giro en la relación de la monarquía con los poderes locales. La promo-

${ }^{24}$ Monsalvo Antón, J.M., «Gobierno municipal, poderes urbanos y toma de decisiones en los concejos castellanos bajomedievales (consideraciones a partir de los concejos salmantinos y abulenses)», en: Las sociedades urbanas en la España medieval (XXIX Semana Estudios Medievales Estella, 2002), Pamplona, 2003, págs. 409-488.

${ }^{25} \mathrm{La}$ capacidad de las comunidades pecheras para movilizar sus demandas es valorada por Monsalvo ANTÓN, J.M., «Percepciones de los pecheros medievales sobre usurpaciones de términos rurales y aprovechamientos comunitarios en los concejos salmantinos y abulenses», Edad Media, 7 (2005-2006), págs. 37-74.

${ }^{26} \mathrm{La}$ conflictividad plurisecular es reconocida por LORENZO PINAR, Francisco e IZQUIERDO Misiego, José Ignacio, «Términos redondos y despoblamiento en Ávila al inicio de la Edad Moderna. Aproximación histórica», Studia Zamorensia. Segunda etapa, I (2002); LORENZO PINAR, F. e IZQUIERDO MisIEGO, J.I., "Ventas jurisdiccionales abulenses en tiempos de Felipe III y Felipe IV», Studia historica (Moderna), 23 (2001), págs. 199-231. 
ción de las aldeas a la condición de villas comporta, entre otras cuestiones, la provisión de los espacios comunales respectivos y las licencias dadas a los lugares para disponer de términos privilegiados exentos de la comunidad de pastos ${ }^{27}$.

Veamos un ejemplo: En 1393 Enrique III concede carta y privilegio de villazgo al concejo de La Adrada, lo cual implica su separación jurisdiccional del concejo cabecera de Ávila ${ }^{28}$. La medida, reiterada en muchos otros casos, pretende limitar la autoridad que las ciudades han adquirido y ganar la lealtad de los núcleos menores ${ }^{29}$. Esta táctica del poder central favorece la preservación de las tierras comunitarias y fortalece sus bases de apoyo, en el marco de la construcción de alianzas con los principales del reino. El otorgamiento de espacios colectivos a los nuevos concejos, así como la provisión de espacios a los ya existentes, dadas las reiteradas quejas por la estrechez de sus términos, responde a la necesidad del poder central de intervenir en el juego con y entre los poderes locales ${ }^{30}$.

El papel de la monarquía es central en la resolución de los conflictos. Las comunidades campesinas, surcadas por rivalidades internas y en pugna con los poderes superiores, acuden al soberano, en tanto éste se ha reservado el dominio eminente de los términos. La propiedad última, por un lado, y su potestad jurisdiccional, por el otro, le permite asumir un papel arbitral en las disputas ${ }^{31}$,

27 Diago Hernando, M., Soria en la Baja Edad Media...

28 «Y es mi merced que vos, el dicho lugar de La Adrada, que yo fago villa, ayades por termino e por cosa vuestra para vosotros todo el termino que vos aviades e de que hussavades a vos pertenesçia en cualquier manera seyendo aldea, con sus dehesas e montes e prados, aguas corrientes, estanques e con todas las cassas e poblados e alixares e vecinos e moradores que moran e moraren en todo el dicho termino», LuIs LóPEZ, Carmelo, Documentación medieval de los archivos municipales de La Adrada, Candeleda, Higuera de las Dueñas y Sotillo de la Adrada, Institución Gran Duque de Alba, Ávila, 1993, pág. 53.

${ }^{29}$ El otorgamiento a las comunidades aldeanas de tierras y poder de coacción se reitera en el caso de El Colmenar, cuando Enrique III ordena «porque el dicho lugar del Colmenar se pueble e faga mejor, fago villa e lugar sobre sí (...) que pongan forca e tengan carçel e çepo e cadena e otras presiones cualesquier (...) Et es mi merçet que vos el dicho lugar del Colmenar, que yo fago villa, ayades por termino e por cosa vuestra para vosotros todo el termino que vos aviades e de que usavedes o vos pertenesçian en qualquier manera, seyendo aldea, e con sus dehesas e montes, prados e aguas corrientes, estantes e con todas las casas e poblados e alixares e vecinos e moradores (...)», Barrios Gracía, Ángel, Luis Corral, Fernando, Riaño Pérez, Eugenio, Documentación Medieval del archivo de Mombeltrán, Ávila, Gran Duque de Alba, 1996, Doc. 7, págs. 23-24.

${ }^{30}$ En la primera mitad del siglo XV, Juan II enfrenta la privatización de los términos de los concejos y confirma una merced dada a la ciudad de Ávila por sus antepasados: «(...) E es mi merced que esta dicha donación e merçe, que vos yo fago, que sea firme e estable para siempre, e que vos non sea enbargada nin menguada en ningun tiempo, por razon nin derecho alguno nin poession de fecho (...) que diga la dicha çibdad de Ávila nin las villas de Arenas nin del Colemenar (...) de los dichos alixares que dicen en la Transierra, de que vos fago merçet e donación (...)», Documentación de Mombeltrán, Ciudad Rodrigo, 1432, Doc. 21, pág. 48

${ }^{31}$ El concejo de San Miguel de Serrezuela reclama ante el alcalde abulense, García Gonçalez, la restitución de términos usurpados por Urraca González: «(...) le requerían e afrontavan de parte del dicho señor rrey, así como justicia e juez que era en la dicha çibdat et en su tierra, que fuese luego con ellos al dicho termino (...) sy asi lo feziese, que faria bien e derecho, en otra manera 
presentándose como un poder externo con capacidad de imponerse sobre los poderes locales ${ }^{32}$. Esta capacidad de la Corona de canalizar la conflictividad social proveyendo de los dispositivos judiciales necesarios debe ser validada permanentemente para realizar su capacidad imperativa. La recurrente apelación al poder regio señala la presencia del estado central en la vida de las comunidades. Sin embargo, las reiteradas ocasiones en que la decisión regia es desconocida o incluso contestada abiertamente por los poderosos de los lugares indican los límites que tiene la aludida supremacía regia en las aldeas y villas, cuyas propias estructuras sociales y organizaciones políticas generan fuerzas capaces de eludir el imperio del soberano.

La intervención mediadora de la monarquía procesa la lucha social dentro de los cauces legales e institucionales. Al respecto señala Monsalvo Antón:

«el conflicto se arropaba bajo la forma de disputa legal y política, no como choque de intereses económicos antagónicos; enmascaraba la bipolaridad social; y en él intervenían varios agentes políticos internos y externos, incluyendo un concejo urbano defensor de los derechos públicos, pero también, y de forma destacada, la monarquía y su justicia. Es decir, al ser procesado políticamente, el conflicto cambiaba de formato»33.

La realización de pesquisas, la demarcación de términos y la selección de testigos habilitados implican una forma de disciplinar el conflicto, evidenciada en la retórica de los documentos ${ }^{34}$. La solución de los pleitos estuvo inicialmente en manos de los jueces y regidores locales designados por los propios concejos, pero la presencia de miembros de las oligarquías concejiles entre los principales usurpadores obligó a habilitar otras instancias ${ }^{35}$. Juan II resuelve enviar jueces nombrados específicamente para entender en el tema, pero allí surge el problema de su financiamiento. Si bien originariamente los salarios corren por cuenta del rey, efectivamente esta responsabilidad recae en los $\operatorname{concejos}^{36}$. Los

dixieron que protestavan de se querellar dél al dicho señor rrey o a quien de derecho deviesen (...)», Luis López, C. y Del Ser Qujano, Gregorio, Documentación medieval del Asocio de la Extinguida Universidad y Tierra de Ávila, II Tomos, Ávila, Gran Duque de Alba, 1990-92, T. I., Doc. 55, pág. 121.

32 Monsalvo Antón, J.M., «Usurpaciones de comunales...».

33 IB, p. 101.

${ }^{34}$ Un interesante estudio de los procesos judiciales y de la construcción de las estrategias defensivas de las comunidades como «un constructo juridificado», en base a un pleito de 1503 entre la ciudad de Cuenca y el apropiador Alonso Carrillo, en Jara Fuente, José Antonio, "'Que memoria de onbre non es en contrario'. Usurpación de tierras y manipulación del pasado en la Castilla urbana del siglo XV», Studia Historica, (Medieval), 20-21 (2001-2002), págs. 73-103.

35 Véase el caso de los regidores abulenses implicados en la usurpación de tierras comunes, Asocio, T. II, Doc. 193.

36 «Yo enbiaré a las çibdades e villas e lugares que lo pidieren, con mi poder, buenas personas que lo vean e, sabida la verdat, provean e fagan conplimiento de justicia, a los quales mandaré pagar e tasar sus salarios del dicho medio cuento de maravedíes, que para ello dades (...)», Ciudad Rodrigo, Doc. 164, marzo de 1434, pág. 241. 
jueces corregidores se hacen cargo de muchos de los procesos limitando los abusos de los funcionarios locales, pero promoviendo otros ${ }^{37}$.

La mayoría de las sentencias favorecen la restitución a las comunidades del usufructo libre de sus términos ${ }^{38}$, en franca oposición con los intereses de los grandes apropiadores. Con estos fallos se pretende asegurar el equilibrio social y productivo local, en tanto la tierra comunal constituye un complemento necesario de la subsistencia campesina ${ }^{39}$, a la vez que proteger los propios intereses monárquicos, atendiendo a la reproducción de sus tributarios ${ }^{40}$. El resguardo de la base social lleva a enfrentar los intentos de señorialización de los grandes usurpadores. La invasión de términos acompañada de la imposición de poderes coactivos erosiona la jurisdicción regia, con la consecuente pérdida de pecheros, y constituye una grave amenaza para el poder político central ${ }^{41}$. Esta modalidad de la intervención regia debe comprenderse en clave de los antagonismos que se despliegan dentro del bloque de poder. Hacia el siglo XIV y más aún en el XV, la imagen de un rey justiciero capaz de recomponer una situación generalizada de «merma de justicia» expresa no sólo una poderosa convicción por parte de los dominados, sino una estrategia discursiva que obliga al

37 «(...) yo podia saber por verdad quelos corregidores non fazian justicia (...) e que curavan mas de allegar dinero e poner escandalos e çismas e mal querencias entre los pueblos (...) es mi merced de non proveer de aquí delante de corregidor ala çibdad o villa o lugar», Cortes de León y Castilla, Madrid, Real Academia de la Historia, T. II, 1863, Cortes de Zamora de 1432, Pet. 11, pág. 126.

38 «(..) se probaba asaz quanto conplía de derecho que el dicho echón que dicen de Pennalbueytre...que eran términos e pinares de la dicha çibdat de Ávila e pastos conçejales e comunales de la dicha çibdat e de los caballeros e escuderos e pecheros della e de sus terminos», DEL Ser Quijano, G., Documentación medieval del Archivo municipal de San Bartolomé de Pinares (Ávila), Ávila, 1987, Doc. 15, pág. 42.

39 Los pecheros de Trujillo piden al enviado de Juan I que desacote un berrocal para su uso agrícola, en tanto su privatización obstaculiza la reproducción campesina: «(...) vos denunciamos e fazemos saber que el berrocal de aquí de Trujillo de en derredor de la villa (...) que es exido comunal del dicho conçejo para lavor de pan e para pasto e leña e aguas e caça para todos los vecinos e moradores desta villa, asy caballeros e escuderos e pobladores e seyendo exido comunal para todos en comunalmente, algunos de los que an de ver fazienda del conçejo desta dicha villa pusieron e ponen enbargo en la lavor del dicho berrocal, por el qual enbargo nosotros e otros muchos omes e mugeres menesterosos que non avemos heredades de nuestro (...) viene de cada dia muy grant daño a todos los sobredichos por quanto el dicho berrocal es muy provechoso para esta villa quando se labra», SÁnchez Rubio, María de los Ángeles, Documentación medieval del Archivo municipal de Trujillo (1256-1516), Parte I, Cáceres, Institución Cultural El Brocense, 1992, Doc. 46, pág. 57.

40 Alfonso XI reconoce la situación «(...) quela mi tierra es rrobada e astragada e yrema elas rentas son menguadas (...)», Cortes, T. I, 1861, Cortes de Valladolid de 1325, Pet. 1, pág. 373.

41 Este es el caso de la apropiación de comunes por parte del obispo de Segovia «(...) han fecho e fizieron infiutosamente donaciones e traspasamientos de los dichos terminos, prados e montes e dehesas e pinares a algunas personas eclesiásticas, a fin e con entinçion de que non sean tenudos nin obligados a rresponder nin parecer ante vos sobrillo (...)», Asocio, T. I, Doc. 106, julio 1434 , pág. 443 . 
monarca a hacer realidad su «autonomía relativa» de las fuerzas dominantes del reino ${ }^{42}$.

Las sentencias de los corregidores responden a una combinación entre derecho y costumbre. Por un lado, se sanciona a los usurpadores - concejos, grandes propietarios $^{43}$ e instituciones eclesiásticas ${ }^{44}$ — por no exhibir los títulos legales que justifiquen la apropiación de los términos; por otro, se legitima el derecho consuetudinario de las comunidades a mantener los aprovechamientos comunes por permanecer en ese estado desde tiempo antiguo ${ }^{45}$. Sin embargo, la generalización de las ocupaciones y el compromiso de los grupos de poder en ellas torna ineficiente la acción judicial ${ }^{46}$. Muchos pleitos que concluyen con la restitución de los bienes se reinician por la imposibilidad de aplicar las sentencias. La impericia de los funcionarios sumada a su connivencia con los grandes apropiadores ${ }^{47}$ y la fuerza coactiva de estos convierten en letra muerta muchos de los fallos. Por ello, las reuniones de Cortes se convierten en ámbitos privilegiados de expresión del descontento.

En las Cortes de Madrid de 1329 se aprecian las fluctuaciones de la política regia. Alfonso XI ordena devolver los comunales que la propia monarquía había cedido a particulares enajenándolos de la jurisdicción concejil:

«(...) me pidieron por merçet quelos exidos e montes e terminos e heredamientos que eran delos conçeios, e los yo he tomado por mis cartas a algunos, que tengo por bien gelos tornar (...) mas que ssean para pro comunal delas villas e logares donde son $(\ldots))^{48}$.

\footnotetext{
42 Monsalvo Antón destaca la autonomía de la monarquía frente a los intereses de los bloques sociales concretos, MONSALVO ANTÓN, «Usurpaciones de comunales...».

43 «Fallamos que, ansi por los dichos e depusiçiones de los testigos contenidos en las dichas pesquisas, (...) el dicho Sancho Sánchez no aver mostrado et provado titulo alguno al dicho echo e artuñeros que dicen de Gonçalo Gomez, se prueba (...) ser echo e pasto comuna del dicho conçejo et pueblos (...) el dicho Sancho Sánchez averlo tenido e tenerlo entrado et tomado indebidamente sin titulo legitimo", Asocio, T. I, Doc. 75, enero 1415, pág. 319.

44 «(...) algunos logares e vasallos del obispo de la dicha çibdat tienen entrados e ocupados muchos terminos, prados, montes e dehesas, que diz que pertenecen a la dicha çibdat e a sus pueblos (...)», Asocio, T. I, Doc. 106, julio 1434, pág. 443.

45 Señala un testigo «(...) que siempre viera que un echo que llaman de Vacacocha que se paçia por comun et conçejil de la dicha çibdat e de su tierra (...)", Asocio, T. I, Doc. 70, enero de 1414agosto de 1415.

46 «Pese a las sentencias dictadas por los jueces de términos que intervinieron en los problemas de reducción de los espacios comunales, los resultados no fueron los deseados y los concejos se vieron incapaces de defenderse ante los usurpadores que volvían a ocuparlos», CARMONA RUIZ, M.A., La ganadería..., pág. 200.

${ }^{47}$ El compromiso de oficiales regios en las tomas de tierras es habitual, como el caso del oidor Pero González de Ávila: «(...) quel doctor Pero Gonçalez de Avila, mi oidor, asy en las cosas que faze en esa dicha çibdad (...) en las tomas que tiene tomadas (...) vos ha rrequerido e leydo cartas a vos e a vuestros alcaldes que vos non entremetades a conocer de sus pleitos nin de otras cosas e tomas que diz que asy tiene tomadas a esa dicha çbdad e su tierra, diciendo que por ser my oidor que non vos devedes entremeter», Asocio, T. I, Doc. 103, pág. 438.
}

48 Cortes, T. I, Pet. 48, pág. 420. 
Un siglo después, las Cortes de Zamora de 1432 marcan el inicio de una fase de activa intervención del poder político:

«muchas çbdades e villas e lugares de mis rengos e sennorios, que son demi corona rreal, estavan entrados e tomados muchos lugares e terminos e jurediçiones, por algunos perlados e caballeros e otras personas (...) la potencia de los tales sennores era tanta, que por ello o por el favor e ayuda que tenian en las tales çibdades (...) se quedavan con lo que ansi tomavan, e que por via de plieto non podian alcançar cumplimiento de justicia (...) yo enbiare ala tal çibdad o villa o lugar buenas personas que sepan la verdad desto (...) provean e fagan conplimiento de justicia»49.

Será el paso previo al punto de inflexión de la política monárquica luego de la celebración de las Cortes de Toledo de $1480^{50}$. En esta reunión se expresa el intenso clima de abusos que padecen las comunidades:

«somos informados que muchas çibdades e villas e logares de nuestros rreynos, especialmente de nuestra corona real, estan muy desapropiados e despojados delos dichos sus lugares e jurisdiçiones e terminos e prados e pastos e abrevaderos» ${ }^{51}$.

El recurrente incumplimiento de las sentencias plantea al poder central el problema político de su eficacia imperativa y el peligroso grado de autonomía que han adquirido los poderes locales. La intervención regia pretende subsanar en una misma medida la merma de recursos productivos y la debilidad de su autoridad jurisdiccional:

«(...) e commo quier que tienen sobreello sentencias, no pueden alcanzar la execuçion dellas (...) mandamos que (...) por el mismo fecho el tal ocupador que fiziere resistencia contra la dicha sentencia o mandamiento o fuere contra ella, pierda e aya perdido qual quier derecho que toviere e pretendiere aver, si lo toviere, al sennorio e propiedad de la cosa (...) e que pierdan los ofiçios que toviere, así de nos como de qualquier çibdades, villas e logares, e si no tuviere officio que pierda el tercio de sus bienes para la nuestra camara $(. ..){ }^{52}$.

Las Leyes de Toledo constituyen el principal instrumento para la protección del patrimonio comunal, estableciendo los mecanismos del procedimiento judicial para acelerar y hacer efectivas las resoluciones de los jueces ${ }^{53}$, cuya activi-

${ }^{49}$ Cortes, T. III, 1866, Pet. 12, 1863, págs. 127-128.

${ }^{50}$ Diago Hernando cuestiona la visión generalizada que atribuye a los Reyes Católicos la instauración de una nueva política frente a los comunes, Diago Hernando, M., Soria en la Baja Edad Media...

51 Cortes, T. IV, 1882, Pet. 82, pág. 155.

52 Cortes, T. IV, 1882, Pet. 82, pág. 156.

53 «(...) mandamos que, quando algun concejo se quexare de otro concejo e algunos caballeros e otras qualesquier personas les toman e ocupan sus lugares e juresdiciones e terminos e prados e 
dad se incrementa notablemente desde 1490 . Frente a las numerosas denuncias de los concejos, los pleitos y la expresión de las demandas ante las Cortes permiten la domesticación de un malestar que, no obstante y pese a la débil huella documental, también tiene irrupciones de violencia abierta ${ }^{54}$.

La política regia sobre la propiedad comunal está atravesada por contradicciones determinadas por la constante reformulación de alianzas y las cambiantes orientaciones económicas ${ }^{55}$. Junto a los instrumentos jurídicos y políticos que reprimen la privatización se promueven acciones tendientes a recuperar el control sobre los suelos abiertos otorgados en uso a los concejos ${ }^{56}$, o a preservar los intereses de los apropiadores, legalizando la ocupación ${ }^{57}$ y alentando la subasta de las tierras de titularidad real ${ }^{58}$. La racionalidad que subyace a esta política debe comprenderse reconociendo la dialéctica entre el poder político y la estructuración de las comunidades campesinas, dentro del proceso de transformación del modo de producción.

pastos e abrevaderos (...) que el corregidor u otro juez que dello pudiere e deviere conocer o el pesquisidor que por nos sobre ello fue dado, llame ala otra parte (...) e asigne, e nos por esta ley les asignamos plazo e termino de treynta dias por todos plazos, e los quales no se pueden prorrogar dentro de los quales él aya de mostrar e muestre el titulo o derecho que tiene alos tales lugares (...) e entre tanto el juez o pesquisidor faga pesquisa simplicites, e de plano e sin figura de juicio se sepa la verdad por scripturas e por quantas vias pudieren...», Cortes, T. IV, Cortes de Toledo de 1480, Pet. 82, pág. 155.

54 «(...) vido que quando lo fue a tomar que levó consigo pieça de omes e que fizo echar la rraya con bueys por donde se guardase e que con miedo non ge lo osaron contradezir persona alguna (...) dixo que se los tomara porque era poderoso e que los labradores de la comarca con miedo que non osaron demandarlo (...)», Asocio, T. I, Doc. 74, pág. 260.

${ }^{55} \mathrm{La}$ diversidad y ambivalencia de los distintos grupos sociales e instituciones se expresa en las cambiantes alianzas que reformulan permanentemente la política agraria, DiAGO HERNANDO, M., Soria en la Baja Edad Media...

${ }^{56}$ Es significativo que en un período en el que se destacan los numerosos pleitos con sentencias favorables para el mantenimiento de los pastos comunes se eleven quejas como la que sigue: «(...) por quanto el rey Don Enrique, nuestro señor para sus placeres e deportes ha querido, después que reino en estos Reinos, vedar e apartar, e guardar muchos de los terminos e montes e dehesas, e pastos e exidos de esta villa de Madrid e de su tierra (...)», «Protesta secreta del Concejo contra la usurpación de terrenos del común, llevada a cabo por Don Enrique IV el impotente», en: TimoteO Domingo Palacio, Manual del Empleado del Archivo General de Madrid, con una reseña histórica del municipio, Madrid, 1875, pág. 346.

57 Esto se generaliza en los primeros siglos modernos. Un ejemplo de ello es la entrega que Felipe IV hiciera al duque de Oropesa por su colaboración militar: «(...) para que sin perjuicio de mi corona real (...) podais tomar la cuarta parte de los Valdios de las Villas de Oropesa y Mejorada (...) y hacer en la dicha cuarta parte de Valdios seis dehesas las cuales, podáis cerrar, y romper, y hacer el aprovechamiento que de ellas procediera y arrendarlo y administrarlo según, y como os pareciere (....), SAINZ y SuÁREZ, A., Memorandum sobre el pleito de los Debesones Encinar y Robledo sostenido por el Ministerio fiscal, la villa de Oropesa y pueblos de su antigua mancomunidad, La Calzada, Lagartera, Torralva, Navalcán, Parillas, Alcañizo, Herreruela, Ventas de San Julián y Caleruela, con los Sres. Condes de Oropesa, hoy Duque de Frías, para la Rendición de Cuentas y definitiva reversión de las citadas fincas, Toledo, 1896, pág. 153.

58 Yun Casalilla, B., Sobre la transición al capitalismo en Castilla... 


\section{Política mONÁRQUiCA Y TRANSFORMACIÓN DE LA ESTRUCTURA PRO- DUCTIVA}

La expansión económica de los últimos siglos medievales intensifica el conflicto secular entre agricultura y ganadería. El crecimiento agrícola se da a costa de las roturaciones masivas de las tierras baldías y comunales ${ }^{59}$. Si bien la puesta en cultivo de espacios comunes en ocasiones es autorizada por diferentes ordenanzas desde el reinado de los Reyes Católicos ${ }^{60}$; en muchos casos se trata de acciones que desafían las disposiciones regias ${ }^{61}$. La necesidad de pastos para una ganadería en aumento multiplica las disputas, en tanto a la presión del ganado de labor incrementado por el ascenso agrícola se suma la de la ganadería trashumante ${ }^{62}$.

La cabaña real organizada en la Mesta goza de una serie de privilegios que favorecen la libertad de pastos del ganado que está bajo protección regia, contradiciendo los intereses de los agricultores y de los dueños del ganado estante $\mathrm{e}^{63}$. Entre las prerrogativas concedidas a los mesteños se encuentra la exención de tributos concejiles, en particular del pago del montazgo. Este privilegio reporta para los municipios y principalmente para sus contribuyentes una carga importante, no sólo por la caída de su recaudación sino por los nuevos repartimientos de pedidos destinados a sanear la debilitada hacienda concejil ${ }^{64}$.

59 El reciente debate acerca del concepto de «crisis» agraria en la Edad Media aporta elementos de interés acerca de los conflictos generados por la reducción de los espacios comunales y de las necesidades crecientes del ganado trashumante, véase para el caso de Andalucía, CARMONA RUIZ, M.A., "Ganadería y crisis agraria en Andalucía en la Baja Edad Media», en: Oliva Herrer, Hipólito Rafael y Benito i Monclús, Pere (eds.), Crisis de subsistencia y crisis agraria en la Edad Media, Univ. Sevilla, 2007, págs. 245-257. 1995.

60 CARMONA RuIz, M.A., Usurpaciones de tierras y derechos comunales en Sevilla y su tierra, Madrid,

${ }^{61}$ Este es el caso de las «siembras en rebeldía» que se realizan contra las sentencias dictadas sobre un término, en el álgido año 1490: «(...) dixieron que saben e vieron que al dicho tiempo quel dicho amojonamiento fue fecho, e aquel mismo dia, en començandose a fazer, Juan de Sant Pascual començo a sembrar en el dicho termino (...)», Asocio, T. II., Doc. 182, septiembre 1490-mayo 1491.

${ }^{62} \mathrm{El}$ conflicto entre la ganadería mesteña y las labranzas aldeanas es singularmente intenso en la Tierra de Soria, por la presencia de un fuerte grupo de propietarios de ganado trashumante que mediatiza las relaciones entre las ciudades y las aldeas, DiAgo Hernando, M., Soria en la Baja Edad Media...

${ }^{63}$ La cabaña real, sujeta a la normativa de la Mesta, es protegida por el soberano prohibiendo la existencia de cabañas particulares fuera de ella. Así se pronuncia Juan II: «(...) que ningunos ricos omes ni maestres de Santiago y de Alcántara, ni prior del hospital de San Juan, ni los monesterios de Burgos ni Valladolid, ni del Hospital de Burgos, ni los otros monesterios ni capellanes, ni otros omes algunos del nuestro señorío no ayan cabaña ni cabañas de vacas ni de ovejas, ni de yeguas, ni de careneros, ni de cabras ni cabrones, ni de puercos; salvo que todos los ganados de mis regnos sean de mi cabaña e anden salvos e seguros en mi guarda e defendimiento e en mi encomienda por todas las partes de los mis regnos (...)», Cuaderno de Juan II, Archivo General de Simancas, Diversos de Castilla, leg. 4, $\mathrm{n}^{\circ} 118$.

${ }^{64}$ MANGaS NAVAS, J., El régimen comunal agrario... 
La dominancia de los usos pastoriles a los que se dedican los comunales en los primeros siglos medievales, no obsta para que existan tempranamente, pese a la concesión colectiva, entregas de tierras para cultivo individual. Sin embargo, esta complementariedad de usos será alterada con los primeros cambios en las relaciones productivas.

La labranza de los comunes se orienta a la reproducción de los tributarios, base de sustentación del reino, en tanto la agricultura, prioritariamente de autoconsumo, permite a los pecheros cumplir con las rentas y $\operatorname{censos}^{65}$. Por su parte, la ganadería estante usufructúa las dehesas boyales, ampliadas a finales de la Edad Media, para asegurar el alimento de los animales de labranza ${ }^{66}$. Paralelamente se desarrolla una intensa actividad pecuaria que responde a otro esquema de reproducción económica, basado en la producción de lana para el mercado externo. Los grandes propietarios participan así de un doble circuito: por un lado, se inscriben plenamente en la lógica feudal de producción de valores de uso a través del trabajo dependiente, y por otro, en la producción de valores de cambio en un régimen mercantil simple ${ }^{67}$. Esta dualidad de la formación castellana permite comprender las características singulares del proceso transicional.

Los fenómenos de diferenciación social que experimentan las comunidades de aldea inciden sobre las posibilidades divergentes de evolución estructural. En Castilla, los colectivos campesinos evidencian una fuerte polarización entre sectores enriquecidos, con capacidad de acumulación y de diversificación de las actividades productivas, y una masa creciente de semidesposeídos ${ }^{68}$ que deben apelar a la venta parcial de su fuerza de trabajo ${ }^{69}$. Los obstáculos para acceder a los términos comunes dificultan la reproducción autónoma de estos sectores ${ }^{70}$, reforzando la tendencia a emplearse como mano de obra asalariada. En este sentido, en las regiones con enclaves de industria pañera, como las pujantes ciudades de Cuenca y Burgos ${ }^{71}$, se intensifica la producción de valores de cam-

${ }^{65}$ En el caso de Soria el $70 \%$ de las rentas pagadas eran en trigo, Diago Hernando, M., Soria en la Baja Edad Media..., pág. 88.

${ }_{66}$ Mangas Navas, J., El régimen comunal agrario...

${ }^{67}$ Para un estudio de las condiciones del desarrollo bajomedieval, Astarita, C., Desarrollo desigual en los orígenes del capitalismo, Bs. As., Tesis 11, 1992.

${ }^{68} \mathrm{La}$ incidencia de la renta aparece mencionada como una condición de la progresiva polarización social: «me pedistes por merced deziendo que en algunas çibdades e villas e lugares delos mis rengos los labradores menores son mal levados e destruidos por los pecheros mayores», Cortes, T. II, 1863, Cortes de Madrid de 1433, Pet. 33, pág. 179.

${ }_{69}$ Para un estudio de la diferenciación social desde una perspectiva estructural comparativa, DA GraCA, Laura, «Notas sobre la diferenciación social en señoríos castellanos (Abadengo y realengo, ss. XIV-XVI)», Studia Historica (Medieval), 17 (1999), págs. 231-261.

${ }^{70} \mathrm{La}$ importancia de los comunales como fuente de reproducción de fuerza de trabajo y de afianzamiento de población, ha sido observada por YUN CASAliLla, B., Sobre la transición al capitalismo en Castilla...

${ }^{71}$ Guerrero Navarrete, Yolanda, «Elites urbanas en el siglo XV: Burgos y Cuenca», Revista d’Història medieval, 9 (1998), págs. 81-104. 
bio para los mercaderes empresarios ${ }^{72}$. La política regia que favorece la exportación de lana fuera del reino motiva numerosos reclamos de protección de la producción manufacturera ${ }^{73}$. El problema, si bien excede los alcances del presente trabajo, nos permite situar la cuestión de los comunales dentro del desarrollo general de la estructura productiva del reino, comprendiendo que la oposición entre dedicaciones se inscribe dentro de la tensión entre modelos de producción diferenciados. El destino del patrimonio comunal está fuertemente articulado con este proceso.

Las oscilaciones del poder central en relación a la propiedad común son expresión y mediación de las contradicciones en el nivel de la estructura. La monarquía se debate entre el mantenimiento de los bienes comunes como fuente de subsistencia del campesinado pechero y el avance privatizador sobre ellos, en función de la nueva dinámica de producción. Al mismo tiempo que se procura preservar los espacios colectivos para garantizar parte de la reproducción de los sectores tributarios, se teme que la disponibilidad de tierras abiertas para los segmentos más pobres de las aldeas debilite la actividad productiva. Las Cortes reflejan las quejas por el número de «omes et mugeres baldios» que no se avienen a labrar la tierra, dejando así muchos suelos yermos ${ }^{74}$. Las ciudades demandan a los soberanos medidas de urgencia para asegurar tanto el suministro de fuerza de trabajo como la existencia de superficies cultivables. La abundancia de términos comunes entorpece la conformación de un «mercado de trabajo», acorde a las nuevas necesidades productivas.

El acceso libre a las tierras comunes no debía perjudicar la relación socioproductiva que sostiene todo el régimen social, por ello la regulación de los aprovechamientos comunales tendía a garantizar la provisión de la fuerza de trabajo necesaria para el mantenimiento de las actividades económicas. Este es

72 IrAdiel, Paulino, Evolución de la industria textil castellana en los siglos XIII-XVI. Factores de desarrollo, organización y costos de producción manufacturera en Cuenca, Salamanca, 1974.

73 En las Cortes de Madrigal de 1438 se expresa el ahogo que representa la dependencia del mercado externo ante el alza de los precios: «(...) todas las mercadurias (...) que se compran e venden en vuestros rengos (...) han sobido en muchos mayores presçios delo que solian valer, en especial los pannos mayores de lana que vienen fuera de vuestros rengos (...)», y el perjuicio que representa para la producción local el envío de la lana al exterior: «(...) en los dichos regnos se fazen asaz rrazonables pannos e de cada dia se faran muchos mas e mejores (...) mandar que ningunas lanas non saliesen delos dichos vuestros rengos por mar nin por tierra (...)», Cortes, T. II, Pet. 34, pág. 340.

74 «(...) los de mi tierra et delos mios rengos que pasaban muy grand mengua, por que sse nnon labravan las heredades del pan et del vino et delas otras cossas que ssonmantenimiento delos ommes. Et esto que venia, lo uno por que andavan muchos ommes et mugeres baldios et que non querian labrar, et lo otro por que aquellos que yvan demandavan tan grandes preçios et ssoldadas et jornales, quelos que avian las heredades non las podian conplir», «Ordenamiento de menestrales y posturas otorgado a las ciudades villas y lugares del arzobispado de Toledo y obispado de Cuenca en las Cortes de Valladolid de 1351», Cortes, T. II, pág. 74. La importancia del problema es reiterada en los sucesivos ordenamientos de Sevilla, Córdoba y Cádiz entre otros y en las Cortes de Valladolid de 1351, de Burgos de 1367 y 1373 y de Toro de 1369. 
el caso de la restricción que se impone en las Cortes de Valladolid de 1351 a la práctica del espigueo, permitida únicamente a los sectores considerados improductivos:

«(...) mando que non anden a espigar las mugeres delos yugueros nin delos ssegadores, nin los otros omes et mugeres que ssean para ssegar o para otra obra qual quier fazzer, ssinon las viejas, et moços et moças menores de hedat de doze annos, que espiguen en los restrojos desque fuere ssacado el pan»75.

Los desposeídos absolutos, o aquellos cuya cuantía los ubica por debajo de los recursos mínimos para alcanzar la condición de contribuyentes, constituyen un problema que debe enfrentar la Corona si el número de éstos se incrementa al punto de amenazar la relación de explotación fundamental ${ }^{76}$. La preocupación por estos segmentos marginales en proceso de desclasamiento se enlaza con la generada por la creciente ofensiva de los sectores más poderosos sobre los términos comunes ${ }^{77}$. Ambos fenómenos forman parte de una misma dinámica estructural determinada por la apropiación señorial del espacio en función de la obtención de excedentes comercializables ${ }^{78}$.

\section{La monarquía frente a la Mesta}

La organización de la trashumancia es un aspecto clave de la política de los soberanos, no sólo por la movilización de recursos que la misma compromete, sino en tanto contribuye a la unificación material del reino. La concesión de privilegios a la cabaña real implica que tanto los términos concejiles como los de propiedad privada deben dejar una franja libre para el paso del ganado mesteño, regulación que en principio estimuló la agricultura con la fertilización de

75 Cortes, T. II, «Ordenamiento de menestrales», 42, pág. 88.

76 En el contexto expansivo del XVI, «que no anden pobres por el rreyno, vecinos e naturales de otras partes, syno que cada uno pida en su naturaleza, porque de lo contrario viene mucho daño y se da causa que aya muchos vagamundos e holgazanes», Cortes, T. IV, Cortes de Valladolid de 1523, Pet. 66, pág. 384.

77 «andan muchos omes baldios que son sanos e podrían servir e no quieren (...) e porque non pueden escusar de comer, ponense a furtar e a rrobar e a fazer muchos males andando baldios», Cortes, T. II, 1863, Pet. 32, pág. 20 y «en algunas çibdades e villas de vuestros rengos (...) algunos sennores e personas poderosas que biven enlas dichas villas (...) fazen e quieren fazer agravios e fuerças alas dichas çibdades e villas, asy tomando e provando tomar sus terminos e jurediçion e propios e rentas delas dichas çibdades», Cortes, T. III, Cortes de Madrid de 1435, Pet. 28, pág. 223.

78 «Con independencia de las fases de crecimiento o disminución poblacional, el marginal asalariado en Castilla fue un resultado de la apropiación señorializada del espacio, apropiación que adquirió en la Baja Edad Media una presión exacerbada por la demanda de excedentes para el mercado», AstaRita, C., «Dinámica del sistema feudal, marginalidad y transición al capitalismo», en: CARrillo, S. et Al., Disidentes, heterodoxos y marginados en la historia, Salamanca, 1998. 
los suelos ${ }^{79}$. Sin embargo, las roturaciones de las cañadas reales se convirtieron en un verdadero problema para los ganaderos, que impugnan la política regia de otorgamiento de términos privilegiados a las aldeas ${ }^{80}$. Esta contradicción determina las oscilaciones del poder monárquico entre medidas que favorecen los intereses mesteños ${ }^{81} \mathrm{y}$ aquellas que protegen el patrimonio concejil ${ }^{82}$.

A finales del siglo XIII, Alfonso X concede una serie de privilegios tendientes a institucionalizar la actividad ganadera de larga distancia ${ }^{83}$, entre los cuales figura el nombramiento de los alcaldes entregadores, encargados de ordenar los aprovechamientos agrarios en su conjunto ${ }^{84}$. Sus decisiones suscitan quejas entre los concejos cuando benefician plenamente a los señores del ganado, lo cual motiva la restricción de sus atribuciones por parte de la monarquía ${ }^{85}$. No obstante, la actuación de estos alcaldes no es uniforme y, como señala Marín Barriguete, también perjudica a la Mesta otorgando «licencias a los labradores para la roturación de prados, campos abiertos y vías pecuarias sin importarles la vigencia de lo privilegios, los daños causados a la trashumancia o los precedentes ${ }^{86}$. Estas oscilaciones son indicativas de las propias fisuras de la organización mesteña ${ }^{87}$.

79 CARMONA RuIZ, M.A., La ganadería...

80 Diago Hernando, M., Soria en la Baja Edad Media...

81 «Visytaronse los pastos comunes y concejiles y majadas y abrevaderos del lugar de Miralrio, hallaronse ciertas ocupaciones hechas por personas particulares, fueron condenados cada uno particularmente a que lo dexasen libre para los ganados y fueron condenados en las penas conforme a la provisión de su alteza, pagaron estas penas quatro mill e quinientos maravedies», Relaciones de Alcaldes entregadores, libro 438, citado por MARÍn BARRigueTe, Fermín, «La defensa de las cañadas en el reinado de los Reyes Católicos», En la España Medieval, 9 (1996), págs. 239-273/ 251.

82 A comienzos del siglo XIV, se expresa: «(...) reciben grandes dannos delos ganados que van e vienen a los estremos e salen delas cannadas e entran por los panes e por las vinnas (...) et ssi fueren por otro logar ssinon por las dichas cannadas, quela montadguen ssegund los fueros e los usos de aquellos logares (...) queles demanden ante los alcalles delos logares do acaecieron e que non ayan alcalles apartados los pastores nin entregadores (...) que non ffagan cannada, nin passen los ganados que van a los estremos por los terminos de Valladolit e de olmedo e de Medina», Cortes, T. I, Cortes de Palencia de 1313, Pet. 45, págs. 245.

83 MANGAS NAVAS, J., El régimen comunal agrario...

${ }^{84}$ CARMONA Ruiz, M.A., La ganadería...

85 Argente del Castillo, Carmen, La ganadería medieval andaluza. Siglos XIII-XVI. Reinos de Jaén y Córdoba, Jaén, 1991.

86 MARín BARRiguete, F., «La defensa de las cañadas...», pág. 245. Si bien el autor asocia esta «inconducta» de los alcaldes a que «el cargo se había desligado de la Corona con su conversión en hereditario en 1390», MARÍN BARriguete, F., «La defensa de las cañadas...», pág. 244, consideramos que más allá de los intereses privados que hayan desarrollado estos funcionarios, las fluctuaciones de su accionar se condicen con las características generales de la política monárquica sobre la cuestión.

${ }^{87}$ Diago Hernando, M., Soria en la Baja Edad Media... 
Desde el siglo XIV los pastizales son el principal objeto de usurpación ${ }^{88}$. Las denuncias contra la Mesta por invasión de dehesas acotadas y por su imposición jurisdiccional evidencian el rechazo a la preeminencia de la corporación en los diferentes aspectos de la vida local ${ }^{89}$. La tensión entre la Mesta y los concejos expresa las contradicciones de la estructura del reino entre la superioridad del poder central y la autonomía de las esferas locales. La intervención del poder monárquico responde a la necesidad de imponer su supremacía política en el contexto de una estructuración social que tiende a absorber las medidas centralizadoras en una lógica centrífuga de múltiples núcleos de poder.

La protección del ganado mesteño restringe las atribuciones de los concejos y debilita el crecimiento de los poderes locales, a partir del concepto de soberanía regia implicado en el reconocimiento de la propiedad eminente del soberano sobre los términos baldíos ${ }^{90}$. $\mathrm{Al}$ favorecer a los ganaderos se pretende salvaguardar una actividad productiva que nutre al reino de importantes recursos. Sin embargo, la libertad de pastos se ve interferida por las múltiples exacciones exigidas en las distintas jurisdicciones ${ }^{91}$. La recaudación del montazgo constituye una regalía cedida como facultad discrecional del soberano pero que no se enajena completamente a favor de los concejos. En algunos casos se trata de concesiones que el poder central hace a una comunidad ${ }^{22}$, en otros, simplemente de la apropiación ilegal del cobro de este tributo ${ }^{93}$. Alfonso XI procura concentrar su capacidad imperativa a través de la creación de un nuevo impuesto: el «servicio y montazgo», que consiste en el pago por el paso de los ganados por los puestos reales, preservando el libre usufructo de los pastos comunes ${ }^{94}$.

Los privilegios concedidos obligan a la Corona a enfrentar las contradicciones de su propia política en relación a los concejos y a la Mesta ${ }^{95}$. Los ganaderos

${ }^{88}$ Monsalvo Antón, J.M., «Usurpaciones de comunales...».

89 «quelos pastores dela mesta fazian muchas artes e cohechos, non queriendo yr por sus cannadas faziendo perder el rocio delas yermas a los sennores delas heredades e dehesas de algunos conçejos (...) e que non davan lugar alos ofiçiales delas dichas çibdades e villas e lugares que se entremetiesen de librar por via ordinaria los pleitos que en esta razón acaecían (...) nos pedian por merced que mandasemos que fuesen por sus cannadas non saliendo dellas so çierta pena, e asy quelos sus ofiçiales non se entremetiesen de oír los dichos pleitos», Cortes, T. II, Cortes de Segovia de 1386, Pet. 11, pág. 344.

90 Diago Hernando, M., Soria en la Baja Edad Media...

${ }^{91}$ CARmona Ruiz, M.A., La ganadería...

92 Véase la concesión al Concejo de Sepúlveda, destacada por MANGAS NAVAS, J., El régimen comunal agrario..., pág. 219.

93 Carmona Ruiz, M.A., La ganadería...

${ }_{94}$ KLEIN, Julius, La Mesta. Estudio de la historia económica española. 1273-1836, Madrid, 1990.

95 «(...) que algunas çibdades e villas e lugares de vuestros regnos e sennorios e especialmente el conçejo de la mesta tyenen previllejos de vuestra merced e aun delos reyes pasados a que sus ganados e bienes muebles e semovientes non puedan ser prendados nin esecutados nin enbargados nin detenidos por debdas algunas que devan alos conçejos e lugares donde son vecinos (...) suplicamos a vuestra merced (...) quelos dichos previllejos sean guardados a las tales çibdades e villas 
pretenden legitimar el uso tanto de las cañadas abiertas como de las acotadas y los concejos exigen la eliminación de este derecho. La ofensiva contra la ganadería mesteña es inobjetable desde el siglo XV cuando se ponen en cultivo los términos abiertos concejiles y se amplían las dehesas de los bueyes y otros animales de tiro, a costa de los caminos pecuarios. En las Cortes de Ocaña de 1469 se plantea:

«(...) a muchas personas delos çinco annos a esta parte por su propia autoridad e contra derecho e contra los previllejos dados alos del conçejo dela Mesta (...) algunos se atreven a estrechar las cannadas e caminos fechos para el paso delos dichos ganados (...) por causa delo qual se han rrecresçido alos duennos de los ganados grandes costas e perdidas (...) e presta mente se desharia la cabaña delos ganados destos rreynos» 96 .

Junto con la disminución de las superficies disponibles para el ganado mesteño, la política de los Reyes Católicos, orientada a la preservación del patrimonio público, tiende a revertir los abusos que se derivan del impuesto centralizado sobre el ganado trashumante y de los numerosos tributos que impiden la plena vigencia de la libertad de pastos ${ }^{97}$. Sin embargo, las oscilaciones de la Corona expresan la capacidad de adaptación a la diversidad de elementos que conforman la estructura, articulando alianzas con las fuerzas sociales con las cuales mantiene una relación compleja y muchas veces antagónica.

En el ordenamiento de las Cortes de Alcalá de Henares, el poder central aparece en tensión entre las concesiones realizadas a favor de la Mesta, la preocupante autonomía de los alcaldes entregadores y la necesidad de responder a la demandas de los concejos. La resolución regia respecto de la presión tributaria a la que son sometidas las comunidades es ilustrativa de estos múltiples condicionamientos:

«que los que rrecabdavan el serviçio de los ganados, quando acaecen queles traen los sus ganados de algunos lugares do avien algo alos lugares do moran (...) que les tomavan serviçio de los dichos ganados en cada lugar por do pasavan, e que mandasemos que non tomasen serviçio delos ganados que vienen de una villa a otra (...) salvo

e logares que tienen los dichos previllejos e en especial al dicho conçejo dela mesta», Cortes, T. II, Cortes de Toledo de 1462, Pet. 17, pág. 713.

96 Cortes, T. III, Pet. 15, pág. 797.

97 «Muchas son las querellas que de cada dia nos dan los duennos de los ganados e mercaderes.que resçiven grandes dannos e robos delos que coxen el servicio e montazgo, e de los que piden derechos de pasases e pontaxes (...) e otras imposiçiones en sus ganados e mercaderias (...) impuestas e introducidas algunas imposiciones e nuevos derechos (...) por cartas e licencias del señor rey don Enrique (...) se ha seguido menguamiento e perdimiento dela cabaña delos ganados destos nuestros rreynos e grand agravio delos pastores (...) mandamos que de aquí adelante no se pida ni coxa delos ganados que passaren a estremo a ervajar e de los que salieren del dicho ervaje, mas de un serviçio de montadgo", Cortes, T. IV, Cortes de Toledo de 1480, Pet. 90, págs. 172-173. 
de los ganados que van a estremo (...) A esto respondemos que está agora arrendado por un anno e que nos ponen por esto gran descuento, pero desque esta renta fuere conplida, nos lo mandaremos ordenar porque se pase conmo debe e ellos non rresçiban agravio»98.

La organización de la trashumancia supone no sólo la creación de otro tipo de comunal y el aprovechamiento de los términos concejiles ya existentes, sino la conversión de comunales locales en caminos abiertos para el ganado. Las fuertes luchas por el estrechamiento de cañadas, la imposición de tributos locales o la negativa concejil a respetar la libertad de pastos, señalan este nuevo tipo de conflictividad.

Las formas tradicionales de explotación feudal, basadas en la renta y en la preservación de los pecheros se enfrentan a nuevas relaciones de producción de mercancías. La protección de los comunales locales pretende garantizar la subsistencia campesina dentro de una economía doméstica de producción de excedente para las fuerzas señoriales99; de ello resulta la centralidad del cultivo para los colectivos aldeanos que deben responder a la punción tributaria. A medida que el peso de los tributos a la circulación se torna dominante en la fiscalidad del reino y las rentas tradicionales pierden importancia, la monarquía estimula la producción destinada al intercambio mercantil ${ }^{100}$. Los comunales reales son un soporte importante de la reproducción mercantil simple, proveyendo de materias primas a las industrias domésticas locales o exteriores, como es el caso de la lana que mayoritariamente sale del reino. La obtención de excedente comercializable está asociada a la existencia de rutas para la trashumancia y de los pastos de agostadero y de invernadero. Sin embargo, esta dualidad del patrimonio comunal no representa una oposición antagónica. Por el contrario, la propia ambigüedad de la política regia permite apreciar que las dos formas de comunales, en tanto ámbitos de reproducción de dos lógicas materiales específicas, convergen en el proceso de reestructuración del régimen feudal.

En Castilla, la producción de lana para los grandes circuitos de intercambio no implica la transformación de la estructura feudal hacia formas capitalistas. Por el contrario, la coexistencia de relaciones de dependencia y de nuevas formas de producción y apropiación de excedente favorece la superación de las crisis bajomedievales y consolida un bloque de poder en el que la monarquía integra a sectores no feudales, como las oligarquías villanas. Con la generalización del impuesto de la alcabala ${ }^{101}$, la Corona recupera a través de la comercialización muchos de los tributos perdidos. Por su parte, el cobro de los impuestos sobre el patrimonio

98 Cortes, T. I, 1861, Ordenamiento de peticiones de las Cortes de Alcalá de Henares de 1348, Pet. 43, pág. 697.

99 Diago Hernando, M., Soria en la Baja Edad Media...

${ }^{100}$ LAdero Quesada, M.A., La Hacienda real de Castilla en el siglo XV...

101 Un estudio de la incidencia local de este impuesto para el área abulense en DEL SER QUIJANO, G., «Apuntes sobre la incidencia de las alcabalas en la Tierra de Ávila: Sexmos de San Juan, Covaleda y Santiago», en: Del Ser Quijano, G. y MarTín Viso, Iñaki, Espacios de poder y formas sociales en la Edad Media. Estudios dedicados a Ángel Barrios, Univ. Salamanca, 2007, págs. 255-276. 
comunal, como el aludido servicio y montazgo, cumple una función similar, en tanto desplaza como forma dominante a la renta feudal propiamente dicha.

La transformación de los términos comunales se observa en los litigios en los cuales los propios ganaderos de la Mesta actúan como defensores de estos espacios frente a colectivos campesinos que quieren acotarlos. Lejos de los planteos tradicionales que veían en la Mesta el poder absoluto de una clase feudal fortalecida y sin contradicciones ${ }^{102}$, y de los que revisan el problema desde la perspectiva de una organización débil y en retirada ${ }^{103}$, pensamos la política monárquica sobre la Mesta y la propiedad comunal desde su sustantiva ambivalencia táctica. Ni la Corona es un instrumento de los intereses mesteños, ni la Mesta es una organización señorial por excelencia, ni los reyes favorecen uniformemente a las comunidades. De este modo, las medidas adoptadas a favor de los concejos, muchos de los cuales forman parte de la Mesta, no son necesariamente antagónicas con los intereses de los grandes ganaderos.

\section{Política y POLÍticas de la MONARQUía}

En lugar de una política regia uniforme sobre la propiedad comunal hallamos un conjunto de políticas heterogéneas tendientes a asegurar la reproducción material de los productores y a negociar con las elites locales en función de consolidar el régimen de dominación en las ciudades y las aldeas.

Los diferentes elementos que hemos recogido a lo largo de este estudio nos advierten sobre las dificultades de un análisis coyuntural. La ofensiva sobre la propiedad comunal se observa tanto en momentos de contracción económica como en períodos expansivos. Las urgencias del momento sólo pueden acelerar una disposición regia que responde a un juego político de intereses más vastos y de contenido estructural ${ }^{104}$. La importancia de la coyuntura, que revela el

102 KLeIN, J., La Mesta. Estudio de la historia económica española...; PASTOR, R., Conflictos sociales y estancamiento económico en la España Medieval...; PASTOR, R., "La lana en Castilla y León antes de la organización de la Mesta», en: GARcía MARTín, Pedro y SÁnChEz Benito, José María, (eds.), Contribución a la historia de la trashumancia en España, Madrid, Ministerio de Agricultura, Pesca y Alimentación, 1996, págs. 63-390.

103 Marín Barriguete, F., La Mesta en los siglos XVI y XVII. Roturaciones de pastos, cañadas, arrendamientos e impedimentos de paso y pasto, Madrid, 1987; MARíN BARRIGUETE, F., «Los Reyes Católicos y el Honrado Concejo de la Mesta. Una desmitificación necesaria», Cuadernos de Historia Moderna, 13 (1992), págs. 109-142. Ha introducido la necesidad de matizar el poderío mesteño, Diago Hernando, M., «Caballeros y ganaderos. Evolución del perfil socioeconómico de la oligarquía soriana en los siglos XV y XVI», Hispania, 184 (1993), págs. 451-495; DiAGO HERNANDO, M., «Grandes y pequeños ganaderos trashumantes en las sierras sorianas en el tránsito de la Edad Media a la Moderna», Revista de Historia Económica, año XII, 2 (1994), págs. 343-364.

104 Para el caso de Soria, la usurpación de términos despoblados por la nobleza media local se combina con las mercedes que en recompensa por sus servicios le otorga el poder real, DiAGO Hernando, M., Soria en la Baja Edad Media... 
aspecto financiero de un reino en permanente sangría de recursos, no debe llevar a sobreestimar esta cuestión en detrimento de las causalidades estructurales. Tampoco se trata de una conflictividad causada por ciclos de alza demográfica que vuelca a los hombres a la depredación de los espacios colectivos. Del mismo modo, consideramos que los objetivos fiscales del poder monárquico no son el principal motor de sus políticas sobre la propiedad colectiva. El saneamiento de la hacienda real puede haber impulsado resoluciones puntuales, pero éstas deben inscribirse dentro de una lógica política que contemple el plano material en su vinculación con la reproducción de las superestructuras estatales. Así es como los intereses de recaudación se van modificando a partir de las transformaciones de la estructura. En el largo plazo, el patrimonio comunal pasa de ser protegido como fuente de provisión de renta feudal a ser privatiza$\mathrm{do}^{105}$. Sin embargo, las diferentes formas de "privatización» que la monarquía favorece a comienzos de la Edad Moderna no convierten aún la tierra comunal en propiedad privada, de modo que se niega la plena disponibilidad del propietario que incluye su facultad de enajenarla y transformarla en mercancía ${ }^{106}$. Por su parte, el arrendamiento y fundamentalmente la conversión en bienes de propios de los concejos revierte, al menos en teoría, en un flujo de recursos hacia el poder central ${ }^{107}$.

Frente a cierto «determinismo demográfico-económico» dominante en la historiografía hispánica sobre el tema, Monsalvo Antón propone:

«entender la conflictividad ligada a las usurpaciones no como algo lineal, uniforme y mecánico — las causas que le dieron lugar a (...) — sino como un proceso contradictorio, donde entran en liza proyectos económicos y políticos de las fuerzas sociales que sólo podían ser parcialmente realizados, o pugnas de poder imprevistas, o concurrencia de principios sociopolíticos y hasta de valores que chocaban entre sí»108.

Si bien compartimos esta perspectiva analítica que revaloriza «los factores nacidos de la intersubjetividad y de las relaciones de poder entre los protagonistas en el ámbito local» ${ }^{109}$, consideramos necesario enfatizar el vínculo entre

105 Cabral Chamorro, Antonio, Propiedad comunal y reparto de tierras en Cádiz. (Siglos XVXIX), Cádiz, 1995 y SAnz Rozalén, Vicent, Propiedad y desposesión campesina, Valencia, 2000.

${ }^{106} \mathrm{La}$ venta de tierras baldías, que se intensifica en el siglo XVI, persigue como principal objetivo salvar a la hacienda real asfixiada por las deudas contraídas para financiar la ambiciosa política exterior de Carlos V y Felipe II, sin que se orientara a una transformación socioeconómica de la estructura agraria, MARCOS MARTín, A., «Estructuras de la propiedad en la época moderna...».

${ }^{107} \mathrm{La}$ pérdida del carácter realengo de muchos términos durante el reinado de Fernando e Isabel es producto de muchas concesiones dadas a los concejos para la labranza de las tierras, proveyendo de rentas de propios a las ciudades; se trata, por tanto, de una forma de privatización limitada, Diago Hernando, M., Soria en la Baja Edad Media...

108 MONSAlvo ANTÓN, J.M., «Usurpaciones de comunales...», pág. 108.

109 Monsalvo ANTÓN, J. M., «Usurpaciones de comunales...». 
el aspecto material y la dinámica de poder que actúa en la determinación de las políticas monárquicas.

Las intervenciones de la Corona comprenden desde la concesión de privilegios $^{110}$, con reserva del derecho de propiedad real, la definición del carácter inalienable de los términos, la realización de pesquisas y el envío de jueces, hasta la depredación del patrimonio comunal a través de la venta ${ }^{111}$, el arrendamiento, las perpetuaciones ${ }^{112}$ o bien la legalización de usurpaciones de hecho ${ }^{113}$. Esta diversidad es producto de la disposición objetiva de las diferentes fuerzas en cada nivel de la estructura del reino. Por ello, muchas de las medidas generales del estado tienen a su vez una aplicación específica que responde a la realidad de cada lugar ${ }^{114}$. Si bien muchos aspectos de la vida económica son regulados por los ordenamientos locales ${ }^{115}$, las resoluciones del poder central actúan como fuente generadora de derecho o como instancia de legitimación de normativas concejiles, muchas de las cuales precisan el contenido de los fueros originarios ${ }^{116}$.

La plasticidad con que resoluciones emanadas de la autoridad del monarca son recreadas de acuerdo a las circunstancias de cada concejo expresa la dialéctica entre centralización y particularización propia del feudalismo. La confirmación de privilegios ${ }^{117}$ y casos como los señalados, en los cuales la potestad del

110 Es el caso, entre muchos otros, de la merced alfonsina al caballero Garçi López y transmitida por éste a sus herederos, en virtud de la cual se acotó un pedazo del baldío llamado la Binbre para su aprovechamiento exclusivo, Ciudad Rodrigo, Doc. 19, págs. 42 y 53.

${ }^{111}$ La venta de bienes baldíos se generaliza en el siglo XVI, aunque no se reconoce en ello un ataque a las economías concejiles, ya que muchos de los compradores son los propios concejos que los tenían ocupados previamente de manera ilegal, así lo indica VASSBERG, D., La venta de tierras baldías...

112 Diago Hernando alude a las concesiones a perpetuidad que realizan los Reyes Católicos a ciertas aldeas de Tierra de Soria, Diago Hernando, M., Soria en la Baja Edad Media...

${ }^{113}$ La propiedad común representaba «un importante respaldo económico para los campesinos, en especial para los menos favorecidos. No obstante, sufrió desde antiguo numerosos ataques por parte de la nobleza, de la Corona e incluso de los mismos vecinos, que intentaban ampliar o crear sus propias posesiones», LÓPEZ BENITO, Clara, «Usurpaciones de bienes concejiles en Salamanca durante el reinado de los Reyes Católicos», Studia Historica (Moderna), vol. 1, 3 (1983), págs. 169-183/ 169.

${ }^{114}$ En 1434 Juan II precisa las determinaciones de las Cortes de Zamora de 1432 y de Madrid del siguiente año, para intervenir en la generalizada situación de tomas y apropiaciones del patrimonio comunal en Ciudad Rodrigo, para lo cual dispone: «Yo enbiare a las çibdades e villas e logares que lo pidieren, con mi poder, buenas personas que lo vean e sabida la verdat, provean e fagan conplimiento de justicia (...) restituyendo e faziendo restituyr a la dicha çibdat Rodrigo (...) todo lo que ansí fallardes que está entrado e tomado e ocupado e enbargado (...)», Ciudad Rodrigo, Doc. 164, págs. 241 y 242.

115 LADERo QueSADA, M.A. y GaLÁn PARRA, Isabel, «Las ordenanzas locales en la Corona de Castilla como fuente histórica y tema de investigación (siglos XIII al XVIII)», Anales de la Universidad de Alicante. Historia Medieval, 1 (1982), págs. 221-244.

116 CARMOna Ruiz, M.A., «La organización de la actividad ganadera en los concejos del reino de Sevilla a través de las ordenanzas municipales», Historia. Instituciones. Documentos, 25 (1998), págs. 113-134.

117 En Carta de Enrique IV a la ciudad de Trujillo se observa la adecuación de la normativa general a las condiciones particulares de cada concejo y a la posición específica que éste ocupe 
soberano no alcanza para ejecutar las sentencias ${ }^{118}$, dan cuenta de la lucha entre estas dos tendencias que vertebran la construcción política feudal.

El objeto de este trabajo, las variables formas de intervención regia respecto de la propiedad comunal, remite a los procesos de centralización del estado feudal de los siglos bajomedievales ${ }^{119}$. La construcción de esta forma política superior se expresa en una compleja articulación de instancias institucionales que son el soporte material del reino, a la vez que uno de sus obstáculos. La multiplicación de funcionarios que entienden en la cuestión comunal es al mismo tiempo un requisito de la acción judicial y ejecutiva y una amenaza para la consolidación del poder central.

La conducta fluctuante del poder político frente a la propiedad comunal responde a este balance dinámico de las fuerzas sociales. El estado central no logra imponer su supremacía sobre poderes cuya autonomía relativa, manifestada en los permanentes esfuerzos señorializadores, expresa la propia lógica del feudalismo ${ }^{120}$. De ahí, la constante tensión entre los soberanos y los concejos e incluso entre la monarquía y sus propios delegados, cuando se apropian de potestades públicas ${ }^{121}$.

No puede definirse la política monárquica en un plano abstracto general, ni en términos de un «espíritu proteccionista» o «privatista» de la Corona. Las decisiones regias sólo cobran coherencia si se las estudia en su existencia prácti-

dentro del entramado político y económico general del reino: «Sepades en conmo yo e de aver en cada un año serviçio e montadgo de los ganados de los mis reynos que entran a los estremos e salen dellos e otrosy de los ganados que fueren fuera de sus terminos a vender en las ferias e en los mercados (...) que non levaren alcabala (...) que paguen serviçio dellos (...) delos ganados que fueren fuera de las villas e logares donde moraren e de sus terminos e non obieren serviçiado (...) el qual dicho serviçio e montadgo fue mi merced de mandar arrendar por seys años», Quaderno de leyes del serviçio montadgo, SÁNCHEz Rubio, M.A., Documentación Medieval. Archivo Municipal de Trujillo, Parte III, Ordenanzas Municipales 1415-1517, 1995, págs. 110-111.

118 «(...) e porque ya sobre este mismo termino avia seido litigado ante juez competente entre los dichos sus partes (...) e avina seido dadas sentencias por las quales el dicho termino del Quintanar avía seido mandado restituir e entregar a la dicha çibdad e su tierra e pueblos (...)», Asocio, T. II, Doc. 192.

119 Véase MONSAlvo ANTÓN, J. M., «Centralización monárquica castellana y territorios concejiles (Algunas hipótesis a partir de las ciudades medievales de la región castellano leonesa)», Historia Medieval. Anales de la Universidad de Alicante, 13 (2000-2002), págs. 157-202.

${ }^{120}$ Los esfuerzos de la dinastía Trastámara por imponer la centralización monárquica se manifiestan en una ofensiva legal que incluye el ordenamiento de los bienes públicos y baldíos sobre los cuales crecen las acciones señorializadoras, MONSALVO ANTÓN, J. M., «Usurpaciones de comunales...».

${ }^{121} \mathrm{La}$ concordia celebrada entre Ciudad Rodrigo y el concejo señorializado de Fuenteaguinaldo en 1432 muestra la debilidad de la preeminencia de la potestad regia: «(...) e para cada cosa e parte dello así thener, guardar y cumplir, e pazer, ambas las dichas partes e cada una dellas por sí dixeron que davan e dieron todo su poder cumplido a qualquier juez e justicia o alcalde o alguacil o merino o portero o ballestero o otra qualquier justicia, ansí eclesiástica commo çevil, así de la corte del dicho señor rey como de qualquier çibdad, villar (SIC) o lugar que sea (...)», Ciudad Rodrigo, Doc. 156, pág. 231. 
ca. ¿Qué motiva esta conducta oscilante de la monarquía? La respuesta no puede encontrarse ni en la materialización de un programa como el pretendido por los arbitristas del siglo XVI, ni en las constricciones de la coyuntura financiera o demográfica. Sólo remitiéndonos a la dialéctica de la totalidad es posible alcanzar un grado de comprensión de las impurezas y ambigüedades del fenómeno. Por ello pensamos la política monárquica sobre la propiedad comunal desde una perspectiva amplia de las relaciones de poder en la región.

Recibido: 11-04-2008

Aceptado: 03-07-2008 